\section{Pedagogisk om sårbarhet for folk flest}

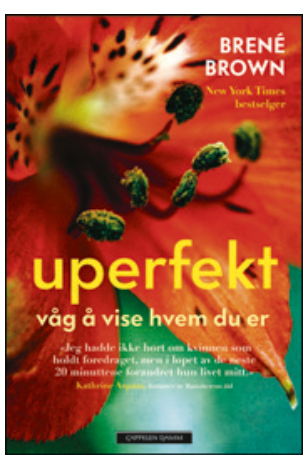

Brené Brown

\section{Uperfekt}

Våg å vise hvem du er. 264 s. Oslo: Cappelen Damm, 2014. Pris NOK 369

ISBN 978-82-02-42753-5

En veltrent, nybakt mor med baby på den ene armen og vekter på den andre strålte på forsiden av Aftenposten lørdag 5. juli under rubrikken «Perfekt kropp er den nye babyen». Etter avisen satte jeg meg ned for å lese Brené Browns Uperfekt.

Brené Brown, professor ved University of Houston Graduate College of Social Work, viser til mer enn ti års forskning på hvordan det å vise sårbarhet, ikke en perfekt fasade, er nødvendig for å få tilknytning til andre mennesker, bli kreativ på jobben eller takle en vanskelig samtale i familien. Perfeksjonisme beskrives som et effektivt - men lammende - forsvar mot skammen vi føler når sårbarheten kommer til syne.

Browns TED-foredrag «The power of vulnerability» fra 2010 er oversatt til 38 språk, og er ett av de ti mest sette foredragene på denne nettsiden med mer enn fem millioner treff (1). Den muntlige, medrivende og pedagogiske fortellerstilen fra TED-foredraget kan gjenfinnes i de sju lettleste bokkapitlene, der hun bruker både Harry Potters univers og Ninja-krigere for å illustrere sine poenger. Hun peker på den gjenkjennelige «knapphetskulturen», der vi opplever at vi ikke er spreke, pene, flinke, snille (kvinner) eller sterke (menn) nok. Videre beskriver hun sårbarhetsmyter, måter å bekjempe skam på og nødvendigheten av å holde ut ubehag for å bli engasjerte og tilstedeværende i forskjellige roller. Hun henvender seg til folk flest, med spesiell adresse til arbeidsliv og familier i de to siste kapitlene. Boken beskriver en amerikansk virkelighet, men som ligger nær (nok?) den norske.

Browns omfattende forskning, med kvalitative intervjuer av nesten 1300 personer, beskrives kort i et Tillegg på slutten. Forskningen er så å si utelukkende publisert på populærvitenskapelig måte, som her. Gjennom boken refererer hun både til egne og andres undersøkelser, men for meg som leser og forsker er det vanskelig å få tak i de direkte sammenhengene mellom resultater og fremstilling. Det gir en usikkerhet hvorvidt tolkning og konklusjoner er holdbare.

Forfatteren beskriver fenomener i dagens samfunn som tar stor plass både i det offentlige rom - som i Aftenpostens artikkel - så vel som i terapirommet. Det er sammenhenger som for de fleste ikke er noen nyoppdagelser, men boken kan anbefales som en pedagogisk og lettlest beskrivelse av viktige dimensjoner i medmenneskelige relasjoner.

Den populærvitenskapelige måten å formidle tematikken på når utvilsomt ut til flere enn den ville gjort i form av forskningsartikler. Kan det, for en professor i en akademisk perfeksjonistisk tradisjon, være en måte å vise sin sårbarhet på, å formidle sin forskning primært på denne måten?

Karin Isaksson Rø

Seniorforsker, LEFO - Legeforskningsinstituttet

Litteratur

1. www.ted.com/talks/brene_brown_on_vulnerability (12.7.14).

\section{Best som muntlig fortelling}

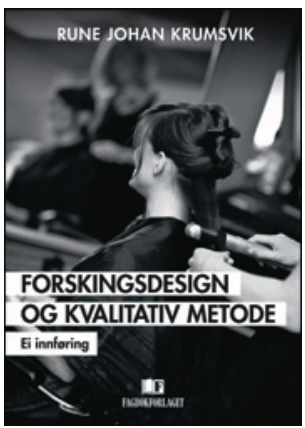

Rune Johan Krumsvik Forskingsdesign og kvalitativ metode Ei innføring. 187 s, ill. Bergen: Fagbokforlaget, 2014. Pris NOK 299 ISBN 978-82-450-1460-0

Denne boken er, ifølge forordet, skrevet som en innføring for studenter som vil bruke kvalitativ forskningsdesign i sin bacheloroppgave. Hvilken relevans kan den ha for Tidsskriftets lesere? Bildet på forsiden viser en ung kvinne som får håret frisert. I bildet er det også et speilbilde som reflekterer de uskarpe konturene av kvinnen og hennes frisør. Omslaget hinter om at boken byr på dybde og kompleksitet, for flere enn ferske forskerspirer.

Hovedpoenget er at en god forskningsdesign har koherens mellom det teoretiske rammeverket, studiens mål, forskningsspørsmålene, metodene, forskningsetiske hensyn og spørsmål om validitet. Forfatteren tar for seg disse elementene etter tur. $\AA$ forklare nybegynnere hvordan epistemologi, metodologi og metode henger sammen i en vellykket forskningsdesign er et ambisiøst prosjekt. Hvordan lykkes han med dette?

Diskusjon av egenarten til kvalitativ forskning tar mye plass, både $\mathrm{i}$ introduksjonen og $\mathrm{i}$ et langt og noe ufokusert kapittel om forskningsmål og teoretiske rammeverk. Her viser forfatteren også hvordan kvalitativ og kvantitativ forskning kan utfylle hverandre i mange prosjekter. Kapitlet om metoder er derimot kort, og studenter vil trenge mer utfyllende litteratur om den metoden de velger til sitt prosjekt.

Jeg ser for meg Krumsvik som en dyktig og inspirerende foreleser for studentene sine. Han har mange gode eksempler og historier, viser videoer og bruker kunnskapsquiz. Boken virker nesten som en nedtegnelse av en slik (ord)rik muntlighet, med lange resonnementer og mange gjentakelser. I den skriftlige formen skulle teksten vært strammet inn, og det burde vært flere avsnitt, undertitler, tabeller, rammer og bokser - slik at fortellingen ble tydeligere ordnet etter tema og de viktige poengene fremhevet.

For meg som er håndlanger på universitetet, bød boken på både nyttige tips, nikk til kjente stemmer i den kvalitative litteraturen og uenige kommentarer i margen. For de fleste bachelorstudenter vil mye av innholdet være helt nytt, og de vil trenge at fortelleren tar dem fastere under armen gjennom forskningsprosessen. Det er en kunst å forklare tydelig uten at kompleksiteten forsvinner ut av blikket.

Hvordan henger epistemologi, metodologi og metode sammen? For den som vil ha en strammere diskusjon av dette, anbefaler jeg artikkelen nedenfor (1).

\section{May-Lill Johansen}

Førsteamanuensis, Institutt for samfunnsmedisin

Universitetet i Tromsø

\section{Litteratur}

1. Carter SM, Little M. Justifying knowledge, justifying method, taking action: epistemologies, methodologies, and methods in qualitative research. Qual Health Res 2007; 17: 1316-28. 